\title{
Human Rights Violations in Myanmar and the Military Junta's Defensive Human Rights Diplomacy
}

\author{
Jatswan S. Sidhu
}

\begin{abstract}
Once considered the internal domain of states, of late human rights issues and concerns have been frequently raised at the international level through the use of human rights diplomacy. However, human rights diplomacy is not only confined to like-minded states who often raise issues pertaining to human rights violations abroad, but can also employed by states violating human rights as a means for its own defence. Under intense criticism for its abysmal human rights record, the Myanmar regime too has often resorted to human rights diplomacy as a strategy to deflect criticism, mainly from without. In doing so, the regime not only often invokes the notion of sovereignty, but even undertakes systematic attacks on the members of the international media and transnational advocacy groups who raise these issues. In addition and knowing that these issues have often dented its own credibility and legitimacy, the Myanmar junta even embarked on an image-building campaign, namely by enlisting the services of foreign public relations firms. In the light of these developments, this article will analyse how Myanmar's military regime has used defensive human rights diplomacy to ward-off criticism against its poor human rights record..
\end{abstract}

Key words: Human Rights Violations, Myanmar, Military Rule, Defensive Human Rights Diplomacy. 


\section{Introduction}

The creation of the global normative architecture by the United Nations that began with the Universal Declaration of Human Rights (UDHR) on December 1948, and which eventually evolved into what is informally known as the International Bill of Human Rights meant that human rights issues and concerns had arrived on the international stage. However, it was not until the mid-1970s that states, namely Western, began emphasizing human rights issues in their respective foreign policies. ${ }^{1}$ Currently, the countries that frequently raise human rights issues and concerns at the international level are mainly from the West or rather those from the developed world, while the rest display little or no concern over these issues. The latter are mainly the developing and less developed countries where not only democracy is yet to take root but where most human

- rights violations occur mainly due to the totalitarian/authoritarian nature of the state. ${ }^{2}$ The arrival of human rights concerns and issues onto the international stage also meant the arrival of human rights diplomacy.

\section{Human Rights Diplomacy}

Human rights diplomacy, as defined by Rein Müllerson, constitutes the use of foreign policy instruments to promote human rights. In addition, it also includes the use of human rights issues for the sake of other foreign policy aims. Human rights diplomacy can be practised unilaterally or even at the multilateral level. At a given time, states normally use both the bilateral and multilateral channels in addressing human rights violations. While the former constitutes criticism, denunciations as well as moral and material pressure, that latter normally takes the form of voting or an initiative at a multilateral forum. In other words, the multilateral level provides a state with yet another avenue in addressing human rights concerns abroad. ${ }^{3}$

물

(2) In

In a narrow sense, human rights diplomacy is mostly reactive rather than proactive, because it frequently deals with effects and consequences, rather than addressing its root causes. ${ }^{4}$ Apart from that, one major characteristic of human rights diplomacy is the presence of hypocrisy among policy makers. This is because rarely is there a clear policy pertaining to human rights violations abroad amongst states. In addition, bilateral human rights diplomacy is, by and large, a fairly uncoordinated effort as it is left to each state to take its own initiative in addressing human rights concerns abroad. ${ }^{5}$

The main objective of employing human rights diplomacy is to alter or influence the behaviour of a target or norm-violating state. In the short-term, this may induce the target state to temporarily reduce or forestall violations, while in the long-run, it is obviously aimed at bringing about some structural change in the political and legislative system of the target state, especially by securing a more solid base for the protection of human rights. ${ }^{6}$ 
Methods or forms of human rights diplomacy are very much dependent on the interplay of various factors. These include, among others, the position of human rights vis-à-vis other areas of policy making, competition among bureaucratic entities, general public opinion, the role of non-governmental or transnational actors, and, last but not least, the national image or identity that a particular state projects at the international level. ${ }^{7}$ On the issue of national image, Forsyth asserts that "national self-image may be part and parcel of a nation's political culture - the sum total of a people's attitudes toward political values and processes."

Generally, two patterns emerge on the posture of a state's human rights policy that can either be assertive or defensive. In pursuing assertive human rights diplomacy, a state may use a variety of means to influence global human rights practices, agreements and institutions. It will also condemn states that violate human rights and pursue those accusations in international forums, or in its bilateral relations with the state. This kind of posture often entails the implication that the assertive state has superior knowledge and practice of human rights when compared with the target state. In recent decades, most Western states have conducted their human rights diplomacy with such broad claims, either implicitly or explicitly. ${ }^{9}$ For example, since the late-1970s and especially since the - end of the Cold War, the United States has often projected itself as a beacon of democracy and champion of human rights concerns, thus frequently raising these issues abroad.

Defensive human rights diplomacy is defined as measures taken by a target state to oppose the assertive diplomacy of other states. This is done by proclaiming state sovereignty and making claims that its human rights record and performance are in accordance with existing local conditions and global agreements. In other words, the frequent invocation of sovereignty and cultural relativism is used to shield international criticism and denunciations of its policies and human rights record. The target state also denies the legitimacy of intrusion by international human rights institutions and foreign interest groups and criticises other states by questioning their standing to undertake assertive diplomacy. ${ }^{10}$ At the very basic level, defensive human rights diplomacy can also mean that the target state simply ignores allegations of human rights violations and/or subordinates them to other national interests. ${ }^{11}$ In doing so, a ruling regime may amplify the existence of an insurgency in the country to justify its hold on power and/or even argue that external interference in its affairs constitute a threat to the security of the state. Further, the target state may even undertake measures to demonise external actors, which is not merely confined to like-minded states but may even include some transnational advocacy groups and members of the international media. ${ }^{12}$

As it deals with very different societies and governments, the method or form of human rights diplomacy very much depends on agents, their interests and possibilities, as well as on the characteristics of the addressees, such that the methods used can vary from quiet diplomacy, open criticism, diplomatic protests and démarches to sanctions. Two extremes emerge when considering actions that states take against human rights violating states. 
On the one hand is a tough and punitive stand, while on the other, is moral suasion that may come with rewards. ${ }^{13}$

\section{Military Rule and Human Rights Violations in Myanmar}

Human rights violations in Myanmar (formerly Burma) are not confined to the period after 1988 alone but can be traced back to 1962, when the country's military first usurped power from the democratically-elected government of Prime Minister U Nu. The period after 1962 not only witnessed the entrenchment of military rule but also saw the military regime introducing draconian laws aimed at tightening its grip on power. These included the detention of major political figures including $\mathrm{U} \mathrm{Nu}$, a ban on all political parties and activity, a tight grip on the domestic media and military campaigns against armed ethnic insurgent groups. ${ }^{14}$

However, it was not until 1988 that human rights violations in Myanmar became an international concern such that it has figured prominently in the foreign policy agendas of such states as the United States, Australia, Canada and the European states. Apart from frequently raising the issue of human rights violations in Myanmar through bilateral channels, these like-minded states have also made many attempts at bringing up these issues at multilateral forums such as the United Nations and Association of Southeast Asian Nations (ASEAN). In fact, it was in 1988 that the international community began taking serious notice of human rights violations in Myanmar, mainly due to the manner in which the peaceful pro-democracy protests were brutally suppressed in that year. ${ }^{15}$ In fact, it is noteworthy to mention that albeit international pressure on the Myanmar junta since 1988, the country's human rights record has shown little improvement but in fact has worsened. Subsequent events in the country are in fact testimonies of how the Myanmar regime has brutally suppressed peaceful demonstrations and practised a zerotolerance policy towards dissent in the country. Generally speaking, human rights violations in the country can be categorised into three major categories, namely those inflicted on the proponents of democracy, the ethnic minorities and the common man.

\section{Myanmar's Defensive Human Rights Diplomacy}

When charges of gross violations of human rights were first levelled against the Myanmar junta in 1988, especially over the excessive use of force to suppress peaceful demonstrations in the country, the usual response of the ruling junta was that of muted silence and/or outright denial. In the aftermath of the 1988 demonstrations and the subsequent nullifying of the 1990 election results, the junta went on a defensive mode by not only denying all allegations of human rights violations but also frequently invoking the issue of sovereignty and nationalism. The focus of this effort has specially targeted the domestic opposition (mainly the National League for Democracy/NLD), like-minded Western states, transnational advocacy groups and the international media. Apart from denying charges of human rights violations, the Myanmar junta has also frequently 
posited itself as an institution that promotes development in the country and working enduringly to eradicate the drug trade. In other words, it has frequently used the notion of development as well as performance legitimacy whenever certain states have raised the issue of its legitimacy in spite of the 1990 elections that gave a clear landslide victory to the NLD.

One of the strategies employed is to project that the human rights conditions in the country had dramatically improved after the 1988 disturbances, and especially since the military take-over in September 1988. In fact, in early 1989, while reporting on the conditions in the country, the State Law and Order Restoration Council (SLORC) stated that "most people are enjoying human rights peacefully within a framework of law." another occasion in 1990, and at the United Nations General Assembly (UNGA), the

- Myanmar representative invoked the notion of cultural relativism by stressing that: ${ }^{17}$

Myanmar is well-known for its unique culture, the hallmarks of which are tolerance and compassion. This cultural environment underpins respect for human rights which are not only protected by law but are observed in practise as a matter of tradition. Discrimination - be it on grounds of race, religion or sex - are non-existent in my country.

All the same, the Myanmar junta also frequently concocts its own version of what constitutes human rights, especially by emphasising "genuine rights", as was stated by the country's former Prime Minister Khin Nyunt in 1992. He noted that "human rights in Burma are genuine rights based on humanitarianism with lofty and pure ideas... Every country upholds human rights to a certain extent and to the level appropriate to the specific conditions of that country." 18

For the purpose of countering allegations of human rights violations foreign media broadcasts were also particularly targeted, especially those by the British Broadcasting Corporation (BBC), Voice of America (VOA), Radio Free Asia (RFA) ${ }^{19}$ and All India Radio (AIR) ${ }^{20}$ To counter news transmitted by all these stations, namely the $\mathrm{BBC}$ and VOA, in 1988, the Myanmar junta commissioned the publication of a book entitled $B B C$, VOA and a Sky Full of Lies. ${ }^{21}$ Further, in 1989, the junta's mouthpiece, The Working People's Daily, began undertaking vitriolic attacks on the AIR, frequently accusing the station of interfering in the domestic affairs of Myanmar and even labelling it as "the voice of the insurgents. ${ }^{22}$ It was also reported in 1995 that the military junta had jammed the broadcasts of the BBC and VOA - which was the first for the BBC's Burmese service in 55 years. ${ }^{23}$ As most of the foreign journalists covering Myanmar are based in Bangkok, The Working People's Daily in June 1991 even described Bangkok as the "haunt of cheap mercenary correspondents." 24

On the same note, in 1997, when the United States' Department of State published its annual report on human rights in Myanmar, the SLORC dismissed the report by stating that the United States was "either extremely ignorant of the true situation" or that the 
report was part of "a conspiracy" aimed at discrediting the Myanmar government. About the same time, it was also reported that Myanmar's military junta had increased the usage of the "democracy jargon" as a means to appease international pressure as well as indicate to the international community that it was undertaking serious political reforms leading towards democratization. ${ }^{25}$ This was, in fact, already the case in 1990 when the country was on the eve of its elections. In a speech delivered by the SLORC's supremo, General Saw Maung, to commemorate the 45th anniversary of the Armed Forces Day, he introduced SLORC's own version of democracy known as "disciplined democracy.",26

\section{The Office of Strategic Studies (OSS)}

- One major actor within Myanmar that was entrusted with the mandate to undertake efforts to counter allegations of human right violations was the Office of Strategic Studies (OSS) at the Ministry of Defence. Apart from countering allegations made by the domestic opposition, the OSS - through its Myanmar Information Committee - had even taken its campaign to the international platform, especially by countering allegations made by some transnational advocacy groups. This was evident in its replies to Amnesty - International (AI), Reporters Sans Frontiéres (RSF) and the International Confederation of Free Trade Unions (ICFTU) that were published in a series of documents known as The Truth which ran into some nine volumes.

One of the works, namely The Truth, Volume Three, Scrutiny of Letters Sent from Members of Amnesty International, is a reply to a series of petitions by Amnesty International's members in various locations around the world that called on the SLORC to release some 80 political prisoners that had been unjustly arrested by the authorities. As such, the volume provides a fairly detailed account on the reasons why these people were arrested, namely due to various offences committed, rather then their respective political inclinations. It also reiterates that AI had made "baseless charges without proper inquiry" and that the petitions were the work of "roadside hooligans hiding behind the mask of human rights" that had "enticed pedestrians and passer-by to sign.",27

Another piece, The Truth, Volume 7, A Review of the Annual Report for the Year 2000 of the Reporters Sans Frontiers, is a response to the 2000 annual report by Reporters Sans Frontiéres (RSF) or Reporters Without Borders. The report stated that "Myanmar is a country where the largest number of news reporters has been incarcerated in jail throughout the entire world." 28 The volume argues that the list of persons mentioned in the report by the RSF did not include any reporters, as at the time of detention they were found to be in other professions and that the arrests were mainly due to offences they had committed. It further reiterates that much of the information in the report "is totally devoid of any vestige of truth" and as the RSF had made these allegations without proper inquiry it therefore "is an organization that lacks professional integrity." 29

On 4 August 1999, the International Confederation of Free Trade Unions (ICFTU) submitted a report to the Director-General of the International Labour Organization (ILO) 
on the issue of forced labour in Myanmar which citied the findings of the Karen (Kayin) Human Rights Group (KHRG). The report alleged that the Myanmar army had been conscripting the use of forced labour for many of its infrastructure projects in the country, especially in ethnic minority areas, and that the practice contravened the conventions of the ILO. The OSS, in its report entitled The Truth, Volume 9, A Scrutiny of the ICFTU Report Based on Reports of the Kayin Human Rights Group that has been submitted to the Director General of the ILO, argued that most of these violations had occurred in areas held by the Karen National Union (KNU). In stark contrast, it also stated that in areas under government control, the local people had voluntarily extended their assistance as "the people hunger for peace and development and truly appreciate the Government's endeavours to develop the region." ${ }^{, 30}$ The volume dismissed the KNU and KHRG as "traitorous groups" that were "bent on discrediting the Government in the eyes " of the international community.",31

Aside from these, the OSS also frequently organised seminars for the country's civil servants, and even made attempts at hosting international events and meetings. While the seminars for the civil servants were obviously a part of the army's indoctrination programme, the hosting of international events and meetings were clearly a publicity - stunt aimed at improving the international image of the Myanmar junta. As for the hosting of international meetings/events, in 1999, Khin Nyunt disclosed that Myanmar would host more high-level international meetings as a strategy because "many nations, including some from [the] Asian region, have been taken in by the falsehoods being spread about Myanmar." 32 Khin Nyunt reiterated that by hosting these meetings, Myanmar would be able to "show visitors the truth about the country, which is accused of widespread human rights abuses. ${ }^{, 33}$ Apart from enhancing international understanding on the situation in Myanmar, Khin Nyunt also stressed that the meetings would also enable Myanmar to attract foreign investments. ${ }^{34}$

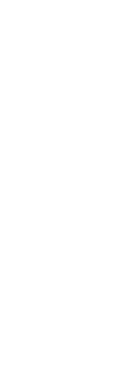

In addition, frequently highlighted in many official statements are the efforts of Myanmar's junta towards the eradication of drug production in the country - a problem that even relegated it to being a nacro-state due to allegations of the regime's close links with the country's drug lords. ${ }^{35}$ Nonetheless, the Myanmar regime has repeatedly used its efforts in eradicating the drug trade in the country as a publicity stunt and bargaining chip, namely with the United States Drug Enforcement Agency (DEA). ${ }^{36}$ The SLORC's work on drug eradication is also frequently highlighted in the country's speeches at the UNGA. $^{37}$ For example, in the 1990 UNGA session, Ohn Gyaw, Myanmar's Foreign Minister, highlighted that the SLORC "continue[s] to intensify our relentless war on illicit drugs" and as a result, in 1990 alone, some US\$921 million worth of heroin and other narcotics drugs were destroyed in Yangon "in full view of the diplomatic corps", while some 163,000 acres had been put under cash-crops in place of poppy cultivation. ${ }^{38}$ This method of incendiary propaganda is frequently used for international consumption and in full view of the foreign diplomatic corps in the country. ${ }^{39}$ 
The fact that the international image of some of Myanmar's minority groups has on occasions been tainted due to their alleged links with the drug trade in fact works in favour of the army because "Rangoon encourages this interpretation and puts forward the view that [the] central government authority offers the best hope [in] eradicating the drug trade." 40 Aside from frequently highlighting its efforts towards drug eradication in the country, the Myanmar junta even established a Drug Elimination Museum in 2001 which amongst others, highlights the work of the Myanmar army in the eradication of drugs since $1962 .^{41}$

The accomplishments of the Myanmar junta in bringing about development to the country have also been a major subject in its efforts to counter allegations of widespread human rights violations. The junta is always quick to capitalise on the infrastructure - projects that it has undertaken, especially in the troubled ethnic minority areas. This is evident in the work entitled Endeavours of the Myanmar Armed Forces Government for National Reconsolidation. In addition, trips to ethnic minority areas where some development has taken place are frequently organised for diplomats based in Yangon as well as foreign visitors. In fact, it was mainly for this purpose that the SLORC invited some forty-six Bangkok-based Thai and foreign journalists for tours of the country - between 18 and 20 January 1989, as part of its strategy to deflect mounting criticism on its abysmal human rights record. ${ }^{42}$ For the same purpose, in October 1996, a symposium was held in Yangon to highlight the SLORC's efforts in bringing about development to the country. Subsequent to the symposium, a volume entitled Socio-Economic Factors Contributing to National Consolidation was also published, being a compilation of some twenty-seven papers presented by local academics, bureaucrats and the staff of the OSS. ${ }^{43}$

\section{The Myanmar Junta and Image Building}

Like the proponents of democracy who resorted to the use of the internet to highlight human rights violations in Myanmar, the country's junta was quick to learn such that it too began resorting to the cyberspace. A report of 1999 stated that the country's junta had started a website known as www.myanmar.com, which was created by an American company based in Laurel, Maryland. The website features news and information about Myanmar. In fact, according to the same source, in 1997, the country's junta had embarked on an aggressive campaign to use the internet, such that in May 1997, it even started its own mailing list known as MyanmarNet. ${ }^{44}$ By doing so, it is obvious that the Myanmar junta had taken its campaign to counter allegations of human rights violations to the cyberspace - albeit with little results in its favour. ${ }^{45}$

In 1998, it was also disclosed that the Myanmar junta had enlisted the services of two American public relations firms for the purpose of lobbying for it. One of the firms, Jefferson Waterman International, was officially hired by Myanmar Resources Development Ltd., a private company that acted as a front for the junta, while another, Bain \& Associates, was enlisted by Myanmar's largest real-estate developer with links to the junta, Zay Ka Bar, for the purpose of positing the junta in a favourable light. ${ }^{46}$ It was 
revealed that Jefferson Waterman International was run by Ann Wrobleski, a former United States' Assistant Secretary of State during the Reagan administration, and was charging the Myanmar junta US $\$ 400,000$ annually, in addition to some US\$100,000 as expenses to arrange for contacts with Congressional and administration officials. Beginning from early 1997, the company also began publishing a newsletter known as the Myanmar Monitor that was aimed at providing "a broad and balanced view" of Myanmar and undertaking efforts in assisting the country to promote tourism. The tourism blitz by Jefferson Waterman International, amongst others, promised potential tourists that by visiting Myanmar they would embark on an experience in a country where "loving, kindness, sympathy, benevolence, mutual regard, respect and humanitarianism evolve out of Buddha's teachings., ${ }^{47}$

- Similarly, Bain \& Associates was paid US\$252,000 a year for portraying to the media "a kinder, gentler Burma." ${ }^{48}$ In line with trying to repair the international image of Myanmar's junta, the main focus of these two public relations firms were on the efforts of the junta in eradicating narcotic drugs in the country. This was obvious in May 1998, when Jackson Bain of Bain \& Associates "shepherded journalists, ambassadors and foreign leaders to a bonfire" in which the Myanmar authorities destroyed narcotics worth some US\$1 billion. ${ }^{49}$ However, according to one source, by March 1999, the contracts of both Bain \& Associates as well as Waterman International were not renewed by the Myanmar junta, mainly due to financial woes faced by the regime at that point in time. ${ }^{50}$

In addition, Union Oil Company of California (UNOCAL), that has huge investments in the natural gas sector in Myanmar, partly financed the establishment of the Burma/Myanmar Forum in 1996 for the Myanmar junta. The main purpose of the forum was aimed at "educating the press, Congress and the public about American foreign policy issues." ${ }^{51}$ In addition, UNOCAL was also reported to have hired Frances Zwenig, a former Congressional staffer, who was then with The International Center - a nonprofit organization. Zwenig and his three other associates, who were former United States policymakers, namely Morton Abraham, a former Ambassador to Thailand, Michael Armacost, who served as Ambassador to the Philippines and Japan, and Richard Armitage, a former Assistant Secretary of Defence, were said to be lobbying on behalf of the Myanmar junta. ${ }^{52}$ Further, in 2002, it was also reported that the Myanmar junta had employed a United States lobbying firm, DCI Associates, for US\$450,000 a year, to help improve its international image and relations with the United States. ${ }^{53}$

\section{Conclusion}

In conclusion, it can be argued that in the face of allegations of human rights violations, most target states do not simply practice a policy of muted silence. Rather, more often than not, they do react whenever such allegations surface. In fact, all these allegations from within and without, undoubtedly draws the state into a process of state socialisation. At the very least, the target state would deny that such human rights violations even 
occurred in the first place. At a later stage, a target state may not just simply refute these charges but even concoct it own version of what constitutes human rights and frequently use the notion of sovereignty to argue that all these allegations constitute an interference in the affairs of a sovereign state. By doing so, the domestic opposition, transnational advocacy groups and like-minded states in fact draw the target state into an argumentative discourse. This is an important level as it marks a shift in the behaviour of the target state and can eventually lead to some form of compliance with international human rights norms. On this point, Risse-Kapen argues that ideas and words do not float around freely but in turn impact the target state, thus resulting in some form of modification in its behaviour. ${ }^{54}$

\section{NOTES}

${ }^{1}$ David P. Forsythe, "US Foreign Policy and Human Rights: The Price of Principle after the Cold War," in David P. Forsythe (ed.), Human Rights and Comparative Foreign Policy, Tokyo: United Nations University (UNU) Press, 2003, pp. 25-26.

- 2 See "The politics of human rights," The Economist, 18 August 2001, p. 9; and "Righting wrongs," The Economist, 18 August 2001, pp. 18-20.

${ }^{3}$ Rein Müllerson, Human Rights Diplomacy, London: Routledge, 1997, p. 5.

${ }^{4}$ Ibid., p. 147.

- 5 Tony Evans, The Politics of Human Rights, London: Pluto Press, 2001, pp. 15-16.

6 Jack Donnelly, "An Overview," in Forsythe (ed.), Human Rights and Comparative

Foreign Policy, pp. 325-326.

- ${ }^{7}$ Jack Donnelly, Universal Human Rights in Theory and Practice, Ithaca: Cornell University Press, 2003, pp. 159.

David P. Forsythe, "Introduction," in Forsyth (ed.), Human Rights and Comparative Foreign Policy, p. 2.

${ }^{9}$ Müllerson, Human Rights Diplomacy, p. 6.

${ }^{10}$ Sanjoy Banerjee, "India's Human Rights Diplomacy," in Forsythe (ed.), Human Rights and Comparative Foreign Policy, pp. 180-181.

${ }^{11}$ Donnelly, “An Overview,” p. 318.

${ }^{12}$ Müllerson, Human Rights Diplomacy, pp. 21-28. 
the Military Junta's Defensive Human Rights Diplomacy

${ }^{13}$ For a very interesting piece on the relationship between compliance to human rights standards and rewards, see Eric Neumayer, "Is Respect for Human Rights Rewarded? An Analysis of Total Bilateral and Multilateral Aid Flows," Human Rights Quarterly, Vol. 25, 2003, pp. 510-527.

${ }^{14}$ See Christina Fink, Living Silence: Burma under Military Rule, London: Zed Books, 2001; and Bruce Matthews, Ethnic and Religious Diversity: Myanmar's Unfolding Nemesis, Visiting Researchers Series No. 3, Singapore: Institute of Southeast Asian Studies (ISEAS), 2001.

See Maung Myint, The International Response to the Democracy Movement in Burma since 1962, Stockholm: Center for Asia Pacific Studies, Stockholm University, 2000.

16 “" $34^{\text {th }}$ SLORC press conference, 7 April 1989," The Working People's Daily, 8 April 1989.

17 "Ohn Gyaw's address at the UNGA," The Working People's Daily, 11 October 1990.

- 18 "Sayings of the SLORC," Asiaweek, 3 January 1992, p. 20.

E

19 “Press Release: Astonishingly Fictitious," Information Sheet, No. A-0286 (I), Yangon: Ministry of Information, Myanmar, 28 January 1998.

20 "Junta attacks radio broadcasts," The Irrawaddy, Vol.7, No. 3, March 1999, p. 4.

- ${ }^{21}$ Address delivered by Senior General Saw Maung of the Defences Services at the 45th Anniversary of the Resistance Day (Armed Forces Day), Yangon: Ministry of Information, Myanmar, 27 March 1990, p. 42.

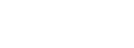

22 "General Saw Maung's meeting with Indian Ambassador," The Working People's — Daily, 28 September 1990; and Bertil Lintner, "Different strokes," Far Easter Economic Review (FEER), 23 February 1989, p. 10.

"BBC, VOA broadcasts jammed by SLORC," Burma Debate, Vol. 2, No. 4, August/September 1995, p. 35; "Burma - radio jammed," FEER, 31 August 1995, p. 13; and "Burma: More radio jammed," FEER,

7 September 1995, p. 13. See also, "Press Release: VOA Misinformed Myanmar Listeners," Information Sheet, No. A-0027, Yangon: Ministry of Information, Myanmar, 8 March 1997.

${ }^{24}$ Martin Smith, State of Fear: Censorship in Burma (Myanmar), ARTICLE 19 Country Report, London: Article 19, December 1991, p. 72. 
${ }^{25}$ Report Card Burma: New Hope, Old Reality, Bangkok: ALTSEAN-Burma, January 2000, p. 17.

${ }^{26}$ Address Delivered by Senior General Saw Maung of the Defence Services at the 45th Anniversary of the Resistance Day (Armed Forces Day), 27 March 1990, p. 57. See also, "Press Release: Positive and Sincere attempt of the Myanmar Government at Dialogue Baffled," Information Sheet, No. A-0136(I), Yangon: Ministry of Information, Myanmar, 22 September 1997.

The Truth, Vol. 3, Scrutiny of Letters sent from members of Amnesty International, Yangon: OSS, Ministry of Defence, Myanmar, 27 September 1999, p. 52. See also, "Press Release: A Response to the Accusations made by Amnesty International,"

- Information Sheet, No. A-0393 (L), Yangon: Ministry of Information, Myanmar, 18 April 1998.

${ }^{28}$ The Truth, Vol. 7, A Review of the Annual Report for the Year 2000 of the Reporters Sans Frontiers, Yangon: Office of Strategic Studies (OSS), Ministry of Defence, Myanmar, 16 May 2000, p. 140.

${ }^{29}$ Ibid., p. 141 .

${ }^{30}$ The Truth, Vol. 9, A Scrutiny of the ICFTU Report Based on Reports of the Kayin Human Rights Group that had been submitted to the Director General of the ILO, Yangon: Office of Strategic Studies (OSS),

Ministry of Defence, Myanmar, 11 July 2000, p. 200.

${ }^{31}$ Ibid.

-

- 32 "Myanmar unveils strategy to improve junta image," Agence France-Presse, 4 February 1999.

${ }^{33}$ Ibid.

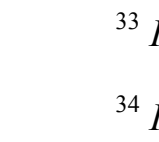

Ibid. See also, "Burma: Asia's first narco-state?," The Irrawaddy, Vol. 6, No. 1, February 1998, p. 11.

See Ronald D. Renard, The Burmese Connection: Illegal Drugs and the Making of the Golden Triangle, Boulder: Lynne Rienner, 1996; and Francois Casanier, "A NarcoDictatorship in Progress: Indifference Confirmed," Burma Debate, March/April 1996, The Burma Project, New York: Open Society Institute, 1996, http:/www.burmaproject.org/burmadebate/MarApril96bttm.html For information on the drug problem along the India-Myanmar border, see India-Burma: Drug Cultivation, Consumption and Trafficking: A Report in the Drug Condition in the India-Burma border areas, New Delhi: Mizzima News, December 2003. 
36 "Press Release: Alternative Development can be Effective in Way to Reduce, and Eventually Eradicate Poppy Cultivation," Information Sheet, No. A-0373 (I), Yangon: Ministry of Information, Myanmar, 2 April 1998.

${ }^{37}$ Two extremely critical reports on the war on drugs by the Myanmar army in the Shan State assert that the former is merely putting up a show when in reality the drug industry is in fact an integral part of its strategy to control the Shan State. See Show Business: Rangoon's "War on Drugs" in the Shan State, Chiangmai, Thailand: Shan Herald Agency for News (SHAN), December 2003; and Show Business: Rangoon's "War on Drugs" in Shan State, (2 ${ }^{\text {nd }}$ Ed.), Chiangmai, Thailand: SHAN, April 2005. See also, Failing Grade: Burma's Drug Eradication Efforts, Bangkok: ALTSEAN-Burma, November 2004.

-

38 "Ohn Gyaw's Address at the UNGA," The Working People's Daily, 11 October 1990. See also, "Burma's phony drug war," The Irrawaddy, Vol. 6, No. 1, February 1998, p. 10.

39 "Up in smoke," The Irrawaddy, Vol. 10, No. 5, June 2002, p. 5. See also, "Press

" Release: Myanmar is Raising Momentum Continuously in Preventing and Eradicating Menace of Narcotics Drugs," Information Sheet, No. A-0387 (I), Yangon: Ministry of Information, Myanmar, 13 April 1998.

40 John Bray, "Ethnic Minorities and the Future of Burma," The World Today, August/September 1992, p. 146. See also, Bertil Lintner, Burma in Revolt: Opium and Insurgency since 1948, Bangkok: Silkworm Books, 1999; and Martin Smith, Burma:

Insurgency and the Politics of Ethnicity, London: Zed Books, 1991.

41 “Drug Elimination Museum,” http://myanmar-narcotic.net/heroin/Drug_Museum.html

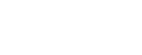

${ }^{42}$ Bertil Lintner, "Masterful inaction,” Far Eastern Economic Review, 2 February 1989, - $\quad$ p. 10.

Socio-Economic Factors Contributing to National Consolidation, Papers and Discussion present at the Symposium held at the International Business centre, Yangon from 9 to 11 October 1996, Yangon: OSS, Ministry of Defence, Myanmar, 1996.

Tiffany Danitz and Warren P. Strobel, Networking Dissent: Cyber-Activists Use the Internet to Promote Democracy in Burma, USIP Virtual Democracy Report, Washington D.C.: United States Institute of Peace (USIP), November 1999, http://www.usip.org/oc/vd/vdr/vburma_html 
45 See Thomas Crampton, "Burma draws an internet weapon in its fight against dissident," International Herald Tribune, 31 August 2000.

46 "Hard to spin this one," Far Eastern Economic Review, 15 October 1998, p. 15.

${ }^{47}$ Ken Silverstein, "The Burma Lobby," Multinational Monitor, Vol. 19, No. 6, June 1998, p. 28.

${ }^{48}$ Deborah Lutterback, "Dollar diplomacy," Far Eastern Economic Review, 7 May 1998, p. 20.

49 "Burma generals buy image-makers," Burma Debate, Vol. 5, No. 1, 1998, p. 25; and

- Lutterback, "Dollar diplomacy," p. 20.

50 "Trade sanctions hit where it hurts: In the PR pocket," The Irrawaddy, Vol. 7, No. 3, March 1999, p. 2; and "Junta fails to pay lobbyists," The Irrawaddy, Vol. 8, No. 1, January 2000, p. 11.

- 51 “Hard to spin this one," p. 15.

${ }^{52}$ Lutterback, “Dollar diplomacy,” p. 21.

53 "Burma thanks human-rights critics," Far Eastern Economic Review, 1 August 2001, p. 9; "Burmese woo Congressional aides," Far Eastern Economic Review, 12 December 2002, p. 10; Glenn Kessler, "Burma moves to improve relations with U.S.," The

- Washington Post, 31 May 2002; and Report Card Burma: New Page, Old Story, Bangkok: ALTSEAN-Burma, September 2002, pp. 33-34; and "Junta bets on better relations with Bush," The Irrawaddy, Vol.10, No. 4, May 2002, p. 5.

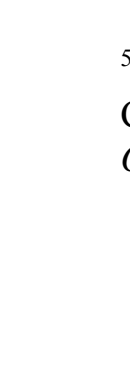

See Thomas Risse-Kappen, "Ideas Do Not Float Around Freely: Transnational Coalitions, Domestic Structures and the End of the Cold War," International Organization, Vol. 48, No. 2, 1994, pp. 185-214. 